\title{
Estimate of dietary intake of chloropropanols (3-MCPD and 1,3-DCP) and health risk assessment
}

\author{
Estimativa da ingestão de cloropropanóis (3-MCPD e 1,3-DCP) e avaliação do risco à saúde
}

Adriana Pavesi ARISSETO ${ }^{1 \star}$, Eduardo VICENTE ${ }^{1}$, Regina Prado Zanes FURLANI ${ }^{1}$, Maria Cecília de Figueiredo TOLEDO ${ }^{1}$

\begin{abstract}
Chloropropanols, including 3-monochloropropane-1,2-diol (3-MCPD) and 1,3-dichloropropan-2-ol (1,3-DCP), comprise a group of chemical contaminants with carcinogenic and genotoxic properties. They have been found in a variety of processed foods and food ingredients, such as hydrolyzed vegetable protein, soy sauce, cereal-based products, malt-derived ingredients, and smoked foods. This study aimed to assess the dietary exposure to 3-MCPD and 1,3-DCP in Brazil and verify whether the presence of these substances in foods could represent health risks. The intake was calculated by combining data on food consumption, provided by the Consumer Expenditure Survey 2008-2009, with the levels of contaminant occurrence determined by gas chromatography-mass spectrometry. The exposure to 3-MCPD ranged from 0.06 to $0.51 \mu \mathrm{g} . \mathrm{kg} \mathrm{bw}^{-1}$.day ${ }^{-1}$ considering average and high consumers, while the intake of $1,3-\mathrm{DCP}$ was estimated to be $0.0036 \mu \mathrm{g} . \mathrm{kg} \mathrm{bw}^{-1}$.day ${ }^{-1}$ in the worst case scenario evaluated. Based on these results, it was verified that the Brazilians' exposure to chloropropanols does not present a significant health risk. However, the consumption of specific foods containing high levels of 3-MCPD could exceed the provisional maximum tolerable daily intake of $2 \mu \mathrm{g} . \mathrm{kg} \mathrm{bw}^{-1}$ established for this compound and, therefore, represent a potential concern.

Keywords: contaminants; processed foods; margin of exposure (MOE).
\end{abstract}

\section{Resumo}

Os cloropropanóis, entre eles o 3-monocloropropano-1,2-diol (3-MCPD) e o 1,3-dicloropropan-2-ol (1,3-DCP), compreendem um grupo de contaminantes químicos com propriedades carcinogênicas e genotóxicas, encontrados em diversos alimentos processados e ingredientes alimentícios, como proteína vegetal hidrolisada, molho de soja, produtos à base de cereais, ingredientes derivados de malte e alimentos defumados. Este trabalho teve como objetivo avaliar a exposição ao 3-MCPD e 1,3-DCP pela dieta no Brasil e verificar se a presença destes compostos em alimentos pode representar um risco à saúde da população. A ingestão foi calculada combinando-se dados sobre o consumo alimentar, fornecidos pela Pesquisa de Orçamento Familiares 2008-2009, com os níveis de ocorrência dos contaminantes, determinados

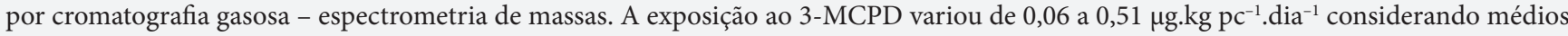
e grandes consumidores, enquanto que a ingestão de 1,3-DCP foi estimada em $0,0036 \mu \mathrm{g} \cdot \mathrm{kg} \mathrm{pc}^{-1}$.dia ${ }^{-1}$ no pior cenário avaliado. Com base nesses resultados, verificou-se que a exposição aos cloropropanóis não representa um risco significativo à saúde da população brasileira. Entretanto, o consumo de determinados alimentos contendo altos níveis de 3-MCPD poderia ultrapassar a ingestão diária máxima tolerável provisória de $2 \mu \mathrm{g} . \mathrm{kg} \mathrm{pc}^{-1}$ estabelecida para este composto e, assim, representar uma preocupação potencial.

Palavras-chave: contaminantes; alimentos processados; margem de exposição.

\section{Introduction}

Chloropropanols are a group of chemical contaminants which can be found in a large variety of foods and food ingredients. They were originally discovered in acid hydrolyzed vegetable protein (acid-HVP) in the 1970 s and 1980 s (VELÍŠEK et al., 1978, 2009), but subsequent studies demonstrated their presence also in soy sauces manufactured with acid-HVP (UNITED..., 1999), as well as in several processed foods and food ingredients, such as cereal-derived products, malt-derived ingredients, and smoked foods (HAMLET; JAYARATNE; MATTHEWS, 2002). The most commonly studied chloropropanols are 3-monochloropropane1,2-diol (3-MCPD) and 1,3-dichloropropan-2-ol (1,3-DCP).

The occurrence of chloropropanols in foods and food ingredients can mainly result from the reaction between chloride ions and lipid components (glycerol or glycero-lipids) during thermal treatment, the use of acid-HVPs (produced with $\mathrm{HCl}$ ), the migration from coating materials treated with epichlorohydrin, the reaction between chloride ions and 3-hydroxyacetone during the smoking processes, or the enzyme-catalyzed hydrolysis of their esters (LÉON et al., 2008; HAMLET; SADD, 2009).

The presence of these compounds in human diet is a concern due to their toxicological properties. It has been shown that 3-MCPD can affect male fertility, kidney functioning, and body weight of rats when regularly ingested in large amounts. Carcinogenic potential has also been observed in rats when 3-MCPD was administrated in high doses over a long period

Received $1 / 8 / 2012$

Accepted 26/10/2012 (005813)

${ }^{1}$ Centro de Ciência e Qualidade de Alimentos - CCQA, Instituto de Tecnologia de Alimentos - ITAL, Av. Brasil, 2880, CP 139, CEP 13070-178, Campinas, SP, Brasil, e-mail: adriana.arisseto@gmail.com

${ }^{*}$ Corresponding author 
of time; however, the contaminant did not demonstrate a significant genotoxic potential in vivo. On the other hand, 1,3-DCP presented hepatotoxic properties, induced a variety of tumours in various organs in rats, and was genotoxic in vitro, and thus it is considered a genotoxic carcinogen that causes cancer by directly damage of genetic material (BAER; DE LA CALLE; TAYLOR, 2010). In 2012, 3-MCPD and 1,3-DCP were classified as possible human carcinogens (group 2B) by the International Agency for Research on Cancer (INTERNATIONAL..., 2012a, b).

The safety of chloropropanols was first examined by the Joint FAO/WHO Expert Committee on Food Additives (JECFA) in 1993 (FOOD...; WORLD..., 1993), followed by two re-evaluations in 2001 (FOOD...; WORLD..., 2002) and in 2006 (FOOD...; WORLD..., 2007). In 2001, the Committee established a provisional maximum tolerable daily intake (PMTDI) of $2 \mu \mathrm{g}$.kg body weight $(\mathrm{bw})^{-1}$ for 3-MCPD on the basis of the lowest observed effect level (LOEL) of $1.1 \mathrm{mg} \cdot \mathrm{kg} \mathrm{bw}^{-1}$.day ${ }^{-1}$ for tubule hyperplasia in the kidney of rats using a safety factor of 500 , but the same approach was considered inappropriate for 1,3-DCP in view of its toxicity (FOOD...; WORLD..., 2002). In 2006, the Committee retained the previously established PMTDI of $2 \mu \mathrm{g} . \mathrm{kg} \mathrm{bw}^{-1}$ for 3-MCPD and derived a BMDL (lower bound of a $95 \%$ confidence interval on a benchmark dose corresponding to a $10 \%$ tumour incidence) of $3.3 \mathrm{mg} . \mathrm{kg}$ $\mathrm{bw}^{-1}$.day ${ }^{-1}$ for 1,3-DCP since carcinogenicity was considered the critical effect of this chloropropanol and a genotoxic mechanism could not be excluded (FOOD...; WORLD..., 2007).

Dietary intake is the main route of exposure to chloropropanols. As a consequence, information about it is necessary to evaluate the potential risks to human health (LÉON et al., 2008). According to data from the European Union, Australia, and Thailand, which were evaluated in 2006 by the JECFA, 3-MCPD intakes ranged from 0.02 to $0.7 \mu \mathrm{g} . \mathrm{kg} \mathrm{bw}^{-1}$. day ${ }^{-1}$ for average consumers and from 0.06 to $2.3 \mu \mathrm{g} . \mathrm{kg} \mathrm{bw}^{-1}$. day ${ }^{-1}$ for high consumers $\left(95^{\text {th }}\right.$ percentile) including estimates for adults, children, and adolescents. When these values were expressed as a percentage of the PMTDI, the results varied from 1 to $35 \%$ for average consumers and from 3 to $115 \%$ for consumers in the high percentile. The Committee noted that the regular consumption of highly contaminated products could result in intakes greater than the PMTDI (FOOD...; WORLD..., 2007).

Based on information provided by the same countries mentioned above, the Committee verified that the estimated intake of 1,3-DCP ranged from 0.008 to $0.051 \mu \mathrm{g} . \mathrm{kg} \mathrm{bw}^{-1}$. day $^{-1}$ and from 0.025 to $0.136 \mu \mathrm{g} . \mathrm{kg} \mathrm{bw}^{-1}$.day ${ }^{-1}$ for average and high consumers, respectively. Since 1,3-DCP is considered a genotoxic carcinogen, risk characterization has been made by using the margin of exposure (MOE) approach, which establishes the margin between a dose causing cancer in animal studies and the estimated human exposure to the substance (EUROPEAN..., 2005). Taking into account the BMDL ${ }_{10}$ and the estimated intakes evaluated by the JECFA in 2006, MOEs of approximately 65000 and 24000 were calculated for average and high consumers, respectively, which were considered of low concern for human health (FOOD...; WORLD..., 2007).

Due to the toxicological properties of 3-MCPD and 1,3-DCP as well as the lack of dietary intake data in Brazil, the objectives of this study were to conduct a preliminary assessment of exposure of Brazilian consumers to these chloropropanols considering the general population and different subgroups, to identify the most important sources of these compounds in the diet, to evaluate the potential health risks associated to the consumption of foods containing these substances, and to verify the need of risk management actions, such as the application of good manufacturing practices and the setting of maximum permitted limits, focusing on the health of consumers.

\section{Materials and methods}

\subsection{Estimate of the dietary intake}

The dietary intake of chloropropanols was estimated by combining food consumption data with occurrence levels of 3-MCPD and 1,3-DCP in foods using a deterministic approach.

\section{Food consumption}

Data on food consumption were obtained from the Consumer Expenditure Survey 2008-2009, which is the most recent of a series of surveys abbreviated as POF (Pesquisa de Orçamentos Familiares) carried out by the Brazilian Institute of Geography and Statistics (INSTITUTO..., 2010a). For the 2008-2009 survey, the questionnaires were expanded to include detailed information on the consumption of food in addition to the usually evaluated indicators such as household food acquisition, anthropometry and nutritional status, expenditure profile, and household availability of food and nutritional conditions.

The information on individual food consumption was provided by the module of the Analysis of Personal Food Consumption in Brazil, in which data were collected from 34003 individuals aged from 10 or over using the method of food record. Each individual took notes of all food consumed inside and outside of the housing unit for two non-consecutive days, in the urban and rural areas of the whole country, over a period of twenty-four hours of the day (INSTITUTO..., 2011).

A total of 1121 food items were mentioned by the participants in the survey, which were combined by the IBGE in a table with 105 foods classified into 21 groups. The present study considered only those foods constituted by at least one item for which data on chloropropanols levels were available. As an example, the food "other leguminous" was selected because "vegetable meat" was investigated for chloropropanols, and it was one of the 20 items that composed this category of food. Therefore, it was assumed that the consumption of an individual food (other leguminous) was only due to the consumption of the food item(s) selected for calculations (vegetable meat).

Table 1 shows the foods considered in this exposure assessment, the items cited in the POF 2008-2009 for which chloropropanols levels were determined, and the mean consumption used to estimate the daily intake by the total population (INSTITUTO..., 2011). Food consumption data reported for subgroups established according to gender (male and female), age (adolescents, adults, and elderly), area of 
Arisseto et al.

Table 1. Mean national consumption of the foods considered in the exposure assessment based on the items reported by the Analysis of Personal Food Consumption in Brazil (INSTITUTO..., 2011).

\begin{tabular}{llc}
\hline \multicolumn{1}{c}{ Food } & \multicolumn{1}{c}{ Selected items that compose the food } & \left.${\text { Consumption }\left(\text { g.day }^{-1} \text {.person }\right.}^{-1}\right)$ \\
\hline Other leguminous & Vegetable meat & 1.3 \\
Breakfast cereal & Cereal bar, corn flakes, granola & 0.8 \\
Instant noodle & Instant noodle & 5.3 \\
Bread & Bisnaguinha, loaf bread, corn bread, French bread, bread not specified, toast & 53.0 \\
Whole bread & Whole bread & 0.9 \\
Cracker & Cracker & 6.8 \\
Sausage & Sausage & 3.3 \\
Frankfurter & Pickled Frankfurter & 2.1 \\
Bologna & Bologna & 1.4 \\
Other processed meats & Smoked turkey breast pâté & 0.7 \\
Cheese & Provolone cheese & 6.8 \\
Chocolate drink powder & Chocolate drink powder, malted drink powder & 0.8 \\
Beer & Beer & 31.1 \\
Baked and fried snacks & Chicken nuggets & 10.1 \\
Industrialized snacks & Chips, extruted snacks & 0.7 \\
Soups and broths & Beef broth, instant soup & 50.3 \\
Sauces and seasonings & Soy sauce & 0.5 \\
\hline
\end{tabular}

residence (urban and rural), and geographic region (North, Northeast, Southeast, South, and Central-West) were also used in this assessment (data not shown).

\section{Levels of occurrence of chloropropanols in foods}

3-MCPD and 1,3-DCP were determined by an in-house validated gas chromatography-mass spectrometry (GC-MS) method in 232 and 172 samples, respectively, including foods containing hydrolyzed vegetable protein (HVP), soy sauces, cereal-based products, foods containing malt-derived ingredients, and smoked foods. The samples were collected in the city of Campinas-SP, Brazil, between 2009 and 2011. For most of the products, two different lots were analyzed.

The sample preparation was carried out according to Brereton et al. (2001) and Lim et al. (2005). Briefly, the homogenized sample ( $8 \mathrm{~g}$ ) was weighed into a $250 \mathrm{~mL}$ beaker. Internal standard solutions of 3-MCPD- $\mathrm{d}_{5}$ and $1,3-\mathrm{DCP}-\mathrm{d}_{5}$ were added to the test portion, followed by $\mathrm{NaCl} 5 \mathrm{M}$. The mixture was homogenized and, after sonication, the Extrelut ${ }^{\mathrm{TN}}$ NT20 refill pack was added and mixed thoroughly. The mixture was transferred to a glass chromatographic column, and the 1,3-DCP was eluted with hexane and diethyl ether (9:1). The 3-MCPD was then eluted with diethyl ether, and the combined extracts were concentrated to a small volume. A portion of the concentrated extract was derivatized with heptafluorobutyrylimidazole (HFBI) at $70^{\circ} \mathrm{C}$ for 40 minutes before injection.

The analyses were performed on a HP 6890 gas chromatograph equipped with a MSD 5973 mass spectrometer (Agilent Technologies, Palo Alto, CA, USA). Helium was used as the carrier gas at a flow rate of $1 \mathrm{~mL} \cdot \mathrm{min}^{-1}$. The Programmable Temperature Vaporizing (PTV) injector was operated in the splitless mode under the following temperature program: started at $100{ }^{\circ} \mathrm{C}$, followed by an increase at a rate of $500{ }^{\circ} \mathrm{C} . \mathrm{min}^{-1}$ up to $280{ }^{\circ} \mathrm{C}$ remaining constant until the end of the run. The separation was performed with a $60 \mathrm{~m} \times 0.25 \mathrm{~mm}, d_{\mathrm{f}} 0.25 \mu \mathrm{m}$ HP-INNOWAX capillary column (Agilent Technologies), and the oven temperature program was: $1 \mathrm{~min}$ at $50{ }^{\circ} \mathrm{C}$, followed by an increase at a rate of $5^{\circ} \mathrm{C} \cdot \mathrm{min}^{-1}$ up to $150{ }^{\circ} \mathrm{C}$ and another increase at a rate of $50^{\circ} \mathrm{C} . \mathrm{min}^{-1}$ up to $240^{\circ} \mathrm{C}$ remaining constant for $2 \mathrm{~min}$. The mass spectrometer was operated in positive electron impact ionization mode (+EI) with $70 \mathrm{eV}$ of electron energy. Selected ion monitoring (SIM) was used for the detection of the following ions: $m / z 278^{*} / 116 / 79$ for $1,3-$ DCP- $_{5}, m / z$ $275^{*} / 110 / 277$ for $1,3-\mathrm{DCP}, m / z 294^{*} / 278 / 456$ for $3-\mathrm{MCPD}-\mathrm{d}_{5}$, and $m / z 289^{*} / 275 / 291$ for $3-M C P D$ ( ${ }^{*}$ quantifier ions).

Table 2 shows the levels of chloropropanols used in the calculations. Mean and P95 concentrations were calculated considering the amounts of the compounds determined in the item(s) according to Table 1. As an example, the chloropropanols levels in breakfast cereal were established based on the concentrations measured in individual samples of cereal bar, corn flakes, and granola. The results of 185 samples analyzed for 3-MCPD and 131 samples analyzed for 1,3-DCP were taken into account considering all foods selected for calculations. Analytical results below the limits of detection (LOD) and quantification (LOQ) were treated according to the Instructions for electronic submission of data on chemical contaminants in foods to GEMS/Food - Appendix 5: Evaluation of low level contamination of foods (WORLD..., 2002). The range indicates the lower and upper bounds of the chloropropanols concentrations for a group of data with more than $60 \%$ of results below the LOQ.

\section{Modelling}

To estimate the intake of chloropropanols using a deterministic approach, a fixed value for the consumption of an individual food was multiplied by a fixed value for the 
Table 2. Concentrations of chloropropanols used in the exposure assessment.

\begin{tabular}{|c|c|c|c|c|c|c|}
\hline \multirow{2}{*}{ Food } & \multicolumn{3}{|c|}{ 3-MCPD $\left(\mu \mathrm{g} \cdot \mathrm{kg}^{-1}\right)$} & \multicolumn{3}{|c|}{ 1,3-DCP $\left(\mu \mathrm{g} \cdot \mathrm{kg}^{-1}\right)$} \\
\hline & $\mathrm{N}$ & Mean & P95 & $\mathrm{N}$ & Mean & P95 \\
\hline Other leguminous & 6 & 102.3 & 177.8 & 6 & $0.0-1.7$ & $0.0-1.7$ \\
\hline Breakfast cereal & 16 & $19.3-22.2$ & 113.0 & 16 & $0.0-2.4$ & $0.0-2.4$ \\
\hline Instant noodle & 5 & 7.9 & 14.2 & 5 & $0.0-1.7$ & $0.0-1.7$ \\
\hline Bread & 28 & 63.4 & 436.9 & - & - & - \\
\hline Whole bread & 4 & $2.8-10.9$ & $9.6-11.2$ & - & - & - \\
\hline Cracker & 5 & 20.9 & 30.8 & 5 & $0.0-2.4$ & $0.0-2.4$ \\
\hline Sausage & 8 & 6.2 & 13.4 & - & - & - \\
\hline Frankfurter & 2 & $0.0-1.1$ & $0.0-1.1$ & 2 & $0.0-1.7$ & $0.0-1.7$ \\
\hline Bologna & 2 & 4.9 & 6.6 & - & - & - \\
\hline Other processed meats & 6 & $1.0-2.5$ & $4.5-5.0$ & - & - & - \\
\hline Cheese & 6 & 22.4 & 46.4 & - & - & - \\
\hline Chocolate drink powder & 6 & $0.0-4.5$ & $0.0-8.8$ & 6 & $0.0-2.4$ & $0.0-2.4$ \\
\hline Beer & 23 & $0.0-3.2$ & $0.0-3.2$ & 23 & $0.0-2.4$ & $0.0-2.4$ \\
\hline Baked and fried snacks & 4 & $0.0-1.1$ & $0.0-1.1$ & 4 & $0.0-1.7$ & $0.0-1.7$ \\
\hline Industrialized snacks & 7 & $3.1-4.1$ & $15.4-15.7$ & 7 & $0.0-1.7$ & $0.0-1.7$ \\
\hline Soups and broths & 12 & 24.9 & 81.6 & 12 & $0.0-1.7$ & $0.0-1.7$ \\
\hline Sauces and seasonings & 45 & $220.6-221.4$ & 621.9 & 45 & $1.3-2.2$ & $0.0-0.9$ \\
\hline
\end{tabular}

$\mathrm{N}=$ number of samples; $\mathrm{P} 95=95^{\text {th }}$ percentile. The range indicates the lower and upper bounds of the chloropropanols concentrations for a group of data with more than $60 \%$ of results below the limit of quantification.

contaminant concentration in this food (KROES et al., 2002). Total exposure was obtained by summing the intakes from all foods (Equation 1).

Intake $=\frac{\sum(\text { Consumption } \times \text { Occurrence })}{\text { Body weight }}$

For average consumers, the intake was estimated by multiplying the mean food consumption by the mean levels of chloropropanols. For high consumers, i.e. individuals who consume large amounts of foods containing the chemical or consume regular amounts of highly contaminated foods, the mean food consumption and the chloropropanols concentration at the $95^{\text {th }}$ percentile (P95) were used.

The intake was expressed on a body weight basis considering the average body weights of the different populations evaluated in this study, which were calculated taking into account the data reported by the survey on Anthropometry and Nutritional Status of Children, Teenagers, and Adults in Brazil, which is also provided by the POF 2008-2009 (INSTITUTO..., 2010b). The average body weight used for the total population was $65 \mathrm{~kg}$, but it varied according to the considered subgroup.

\subsection{Risk characterization}

Since 3-MCPD has been considered a non-genotoxic carcinogen and, in this case, there is a threshold dose below which no adverse effect is observed, the potential risks to human health were assessed by comparing the estimated intakes obtained in the present study with the PMTDI of $2 \mu \mathrm{g} . \mathrm{kg} \mathrm{bw}^{-1}$ established for the development of renal tubular hyperplasia (FOOD...; WORLD..., 2002). The risk may exist if the estimated intake exceeds this reference value.
On the other hand, since no safe level could be established for 1,3-DCP exposure due to its genotoxic potential, the risk was characterized using the margin of exposure (MOE) approach according to equation (2), considering a $\mathrm{BMDL}_{10}$ of $3.3 \mathrm{mg} . \mathrm{kg} \mathrm{bw}^{-1}$.day ${ }^{-1}$ (FOOD...; WORLD..., 2007).

$\mathrm{MOE}=\frac{\mathrm{BMDL}_{10}}{\text { Estimated intake }}$

The MOE approach has been used by risk managers for priority setting in relation to the presence of both genotoxic and carcinogenic compounds in foods, and it suggests that a low MOE value indicates high concern, while a large $\mathrm{MOE}$ value indicates low concern (EUROPEAN..., 2005). Although the interpretation of its magnitude is still under discussion, it has been considered that a MOE of 10000 or higher would be of low concern from a public health point of view, and it might reasonably be considered as a low priority for risk management actions (EUROPEAN..., 2005).

\section{Results and discussion}

\subsection{3-MCPD}

Figure 1 illustrates the estimates of 3-MCPD daily intake based on mean national food consumption data. The total intakes were estimated at 0.08 and $0.44 \mu \mathrm{g} \cdot \mathrm{kg} \mathrm{bw}^{-1}$.day ${ }^{-1}$ for average and high consumers, respectively, considering both the lower and upper bound of 3-MCPD concentrations. At high percentiles, the 3-MCPD intake was approximately 5 -fold higher than the mean. These values are within the ranges of 0.02 to $0.7 \mu \mathrm{g} . \mathrm{kg} \mathrm{bw}^{-1}$.day ${ }^{-1}$ and 0.06 to $2.3 \mu \mathrm{g} . \mathrm{kg} \mathrm{bw}^{-1}$. day $^{-1}$ reported by the JECFA for average and high consumers, respectively 


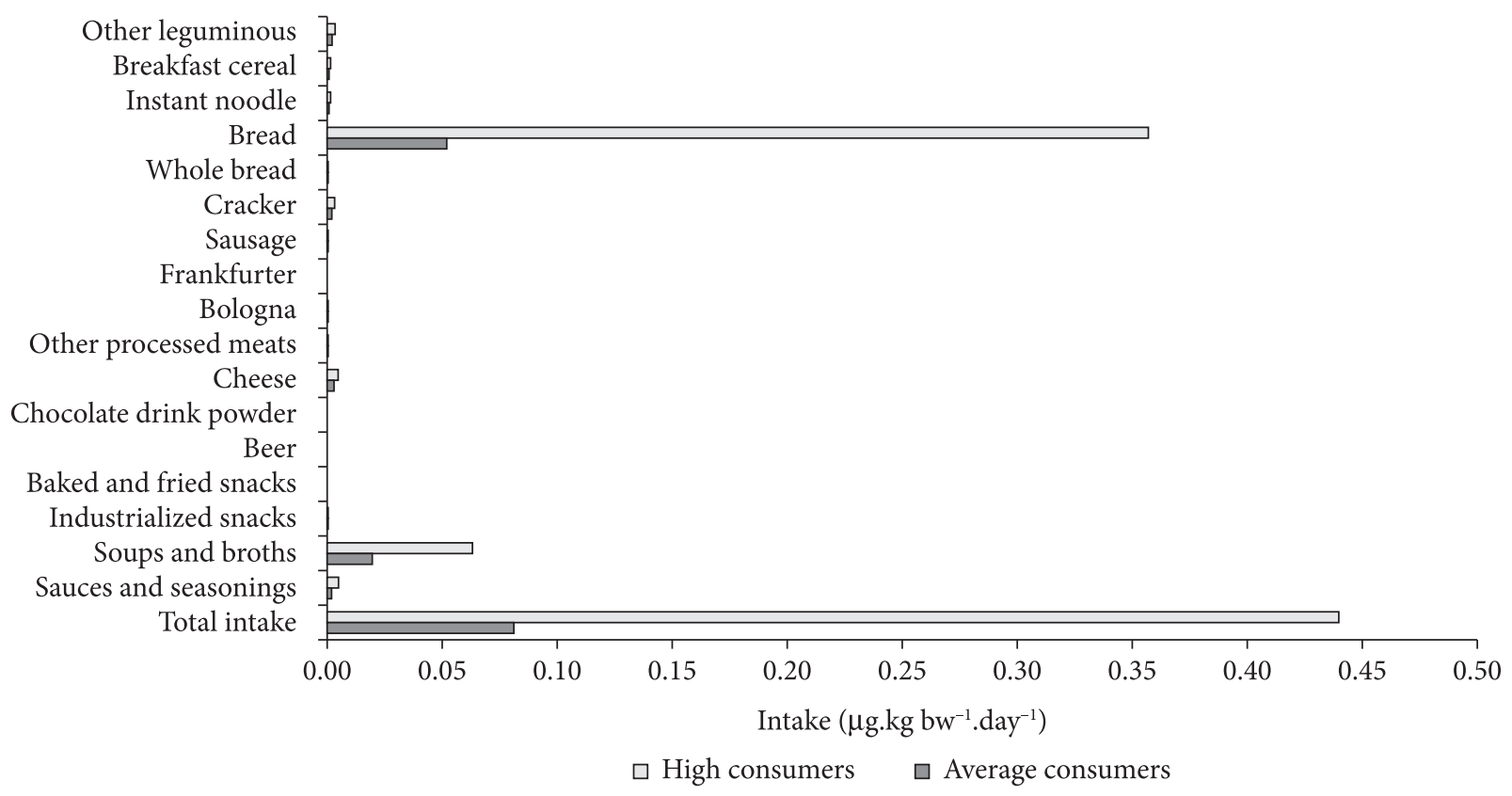

Figure 1. Estimated intakes of 3-MCPD for average and high consumers ( $\mu \mathrm{g} \cdot \mathrm{kg} \mathrm{bw}^{-1}$.day $\left.{ }^{-1}\right)$.

(FOOD...; WORLD..., 2007), and are comparable to the results obtained in other studies (FOOD..., 2007; LÉON et al., 2008).

As can be seen in Figure 1, bread was the most important source of 3-MCPD in the diet, contributing to 63 and $81 \%$ of the total exposure to the contaminant for average and high consumers, respectively. This might be due to the relatively high levels of 3-MCPD found in the analyzed samples of bread, especially at high percentile, and to the significant consumption of this food. The second most important contributor was the group of soups and broths, accounting for 24 and $14 \%$ of the total exposure to the contaminant for average and high consumers, respectively. According to the results reported by other countries, soy sauces and oyster sauces have been identified as the main dietary sources of 3-MCPD for the general population (FOOD...; WORLD..., 2007). However, soy sauces (sauces and seasonings) contributed only to $1-2 \%$ of the overall dietary exposure in this study, which might be due to its low average consumption in Brazil.

The 3-MCPD intakes for the subgroups established according to gender, age, area of residence, and geographic region are shown in Figure 2. The estimates varied between 0.06 and $0.09 \mu \mathrm{g} . \mathrm{kg} \mathrm{bw}^{-1}$. day ${ }^{-1}$ for average consumers and between 0.32 and $0.51 \mu \mathrm{g} . \mathrm{kg} \mathrm{bw}^{-1}$. day ${ }^{-1}$ for high consumers, considering all subgroups. The lowest exposures were observed for the population of rural areas, which could be attributed to the lowest consumption of bread in comparison to the other subgroups. The highest intakes were estimated for adolescents, which might be due to the lower average body weight. With regard to gender, no differences were observed. When considering geographic regions, the population from Central-West presented the lowest exposures levels, while the highest intakes were verified in the Northeast region.

When the dietary intakes estimated were expressed as a percentage of the PMTDI, the results ranged from 3 to $5 \%$ for average consumers and from 16 to $25 \%$ for consumers at the high percentile, considering both the total population and the subgroups evaluated. These results are also comparable to those of other studies (FOOD...; WORLD..., 2007) and suggest that the Brazilian population is unlikely to experience major toxicological effects of 3-MCPD.

\subsection{1,3-DCP}

Dietary exposure to 1,3-DCP for average consumers was estimated to be 0.00001 and $0.0036 \mu \mathrm{g} . \mathrm{kg} \mathrm{bw}^{-1}$. $\mathrm{day}^{-1}$, considering the lower and upper bounds of the mean concentrations, respectively. For high consumers, the intakes were estimated to be zero and $0.0036 \mu \mathrm{g} . \mathrm{kg} \mathrm{bw}^{-1}$. day ${ }^{-1}$, considering the lower and upper bounds of the P95 concentrations, respectively. These values are lower than the estimated intakes reported by Australia and European countries, i.e. from 0.008 to $0.051 \mu \mathrm{g} . \mathrm{kg} \mathrm{bw}^{-1}$. day ${ }^{-1}$ for average consumers and from 0.025 to $0.136 \mu \mathrm{g} \cdot \mathrm{kg} \mathrm{bw}^{-1}$. day ${ }^{-1}$ for high consumers (FOOD...; WORLD..., 2007), and may be associated to the high number of not detected results (98.8\%) obtained in this study. In order to illustrate a worst case scenario of exposure, the intakes estimated using the upper bound concentrations were taken into account (Figure 3).

According to Figure 3, the most important contributors to the 1,3-DCP intake were soups and broths (40\%), followed by beer $(35 \%)$, crackers $(8 \%)$, baked and fried snacks $(8 \%)$, and instant noodle (4\%). According to estimates reported by the JECFA in 2006, meat products have been considered the main contributors to the total intake of 1,3-DCP, ranging from 45 to $99 \%$ depending on the country diet, while soy sauce and soy sauce-based products contributed up to 30\% (FOOD...; WORLD..., 2007). In our study, these foods contributed only to $2 \%$ (frankfurter) and $0.5 \%$ (soy sauce).

The 1,3-DCP intakes for the subgroups established according to gender, age, area of residence, and geographic 

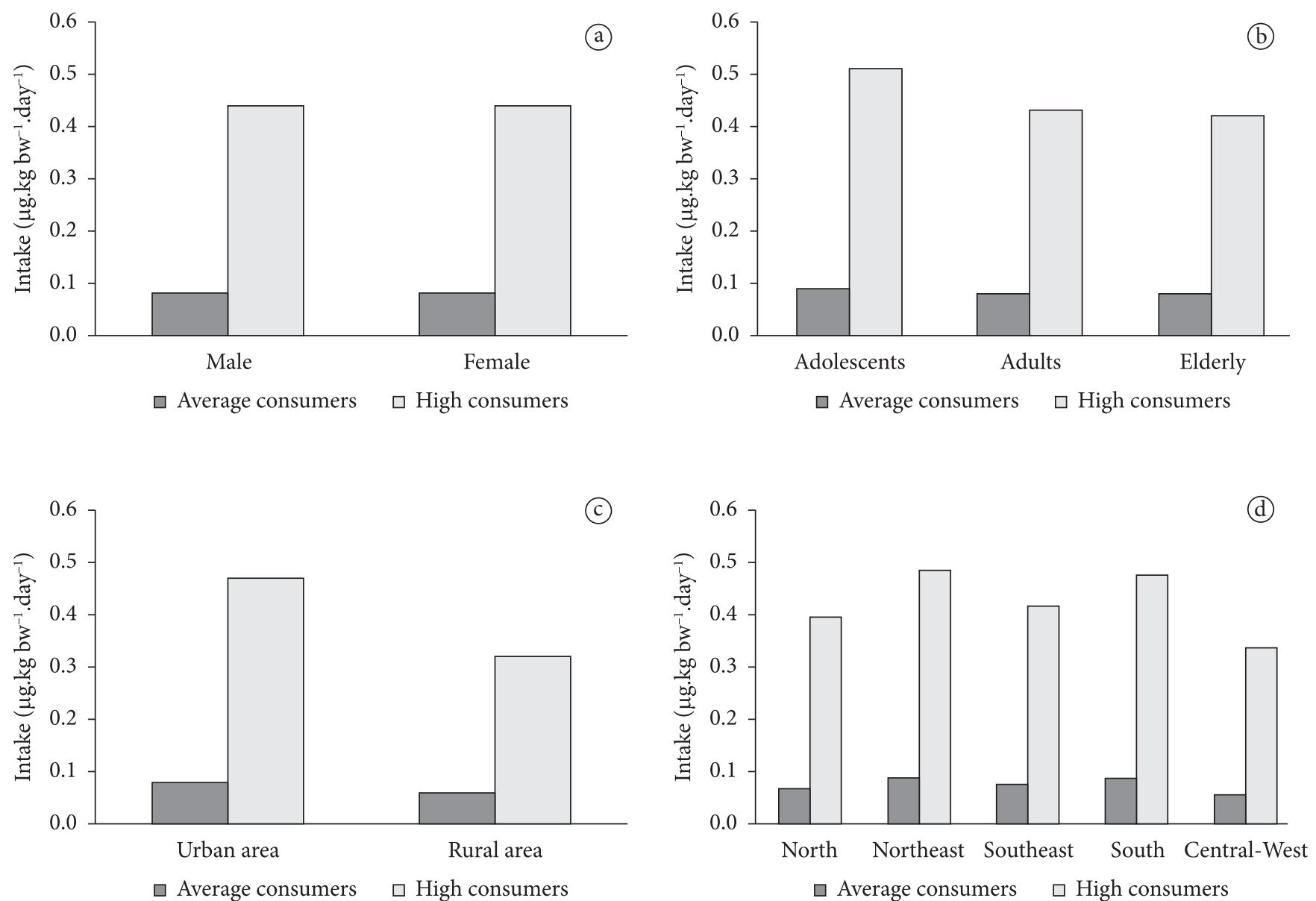

Figure 2. Estimated intakes of 3-MCPD ( $\mu$ g. $\mathrm{kg} \mathrm{bw}^{-1}$.day ${ }^{-1}$ ) according to gender (a), age (b), area of residence (c), and geographic region (d).

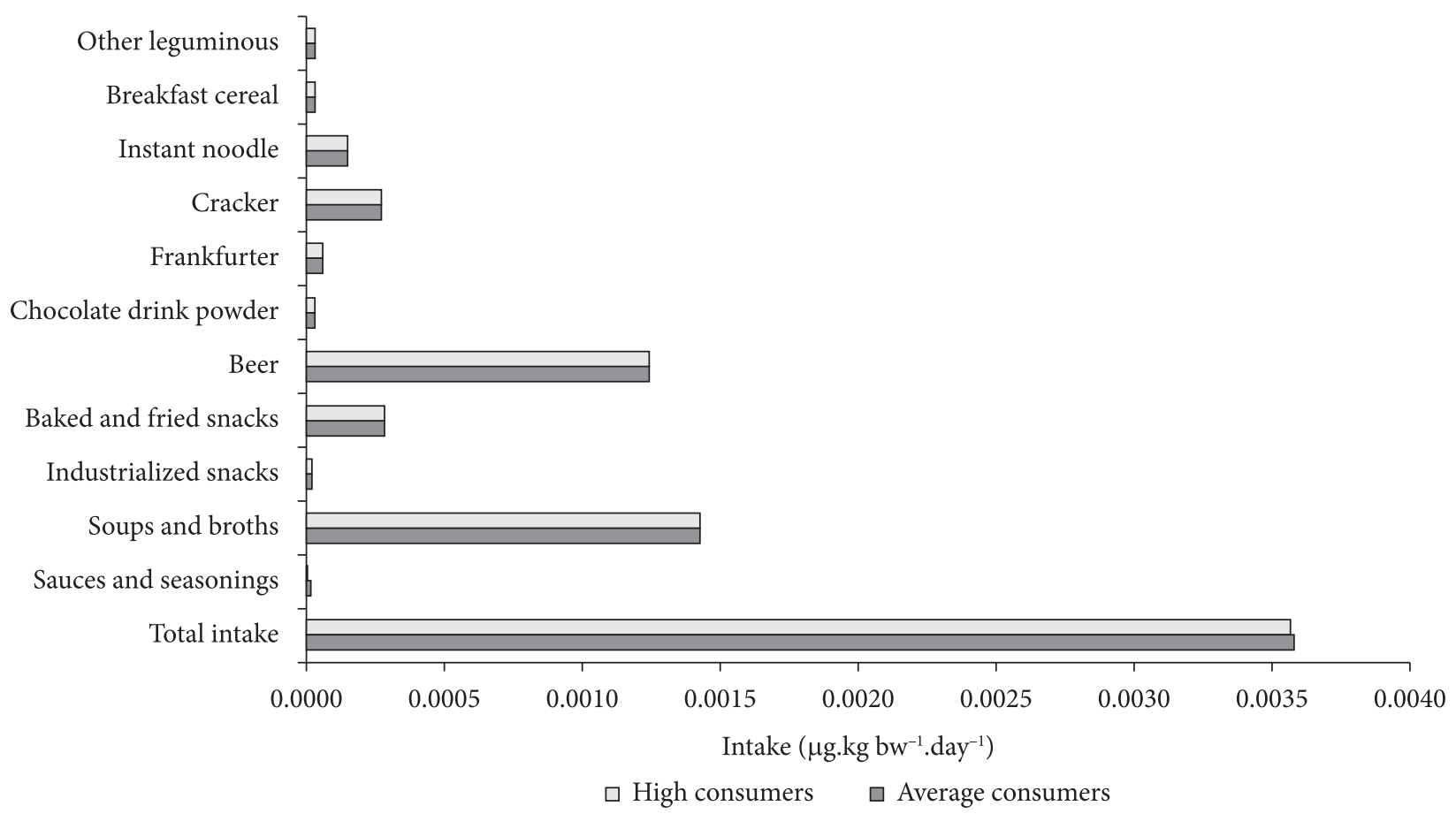

Figure 3. Estimated intakes of 1,3-DCP for average and high consumers ( $\mu$ g.kg bw ${ }^{-1}$.day $\left.{ }^{-1}\right)$ considering the upper bound concentrations. 
region are shown in Figure 4. The estimates varied between 0.0026 and $0.0038 \mu \mathrm{g} . \mathrm{kg} \mathrm{bw}^{-1}$. day $^{-1}$ for average and high consumers considering all subgroups. The lowest exposures were observed for the population of rural areas, while the highest intakes were estimated for men, which might be associated to the higher consumption of beer. As for age, adolescents presented the lowest intakes, while slight differences were observed between adults and elderly individuals. With regard to geographic regions, the population from the Central-West presented the lowest exposure levels, while the highest intakes were verified in the North region.

Using the intakes estimated in the present study, the resulting MOEs ranged from 867717 to 1278510 , considering average and high consumers, respectively, of both the total population and the subgroups evaluated. Such values are even higher than those previously reported (FOOD...; WORLD..., 2007) and suggest that the exposure of Brazilians to 1,3-DCP is of low public health concern.

\subsection{Assumptions and limitations of this study}

The main objective of this study was to provide a general idea of the current situation of chloropropanols intake in Brazil since no information is available so far. Therefore, a deterministic approach (also called point estimate), in which a fixed value for food consumption is multiplied by a fixed value for occurrence level, was initially applied. Point estimates are generally considered to be most appropriate for screening purposes and are commonly used as a first step in exposure assessments because they are relatively simple and inexpensive (KROES et al., 2002; DORNE et al., 2009; JARDIM; CALDAS, 2009). However, inherent in the point estimate models are the assumptions that all individuals consume the specified foods at the same amount, that the contaminant is always present in the foods at an average/high concentration, and that all individuals have the same body weight. In practice, the fixed levels used to calculate point estimates are generally chosen assuming a conservative scenario, so as to be on the safe side when determining the absence of safety concern (DORNE et al., 2009). Therefore, the use of this conservative approach tends to significantly overestimate the resulted exposure (KROES et al., 2002).

For the first time, data on individual food consumption were reported for the Brazilian population in a Consumer Expenditure Survey (INSTITUTO..., 2011). This type of information is much more appropriate for exposure assessment purposes in comparison to the household food acquisition data provided by the POF 2002-2003 (INSTITUTO..., 2004). As previously mentioned, it was assumed in this study that
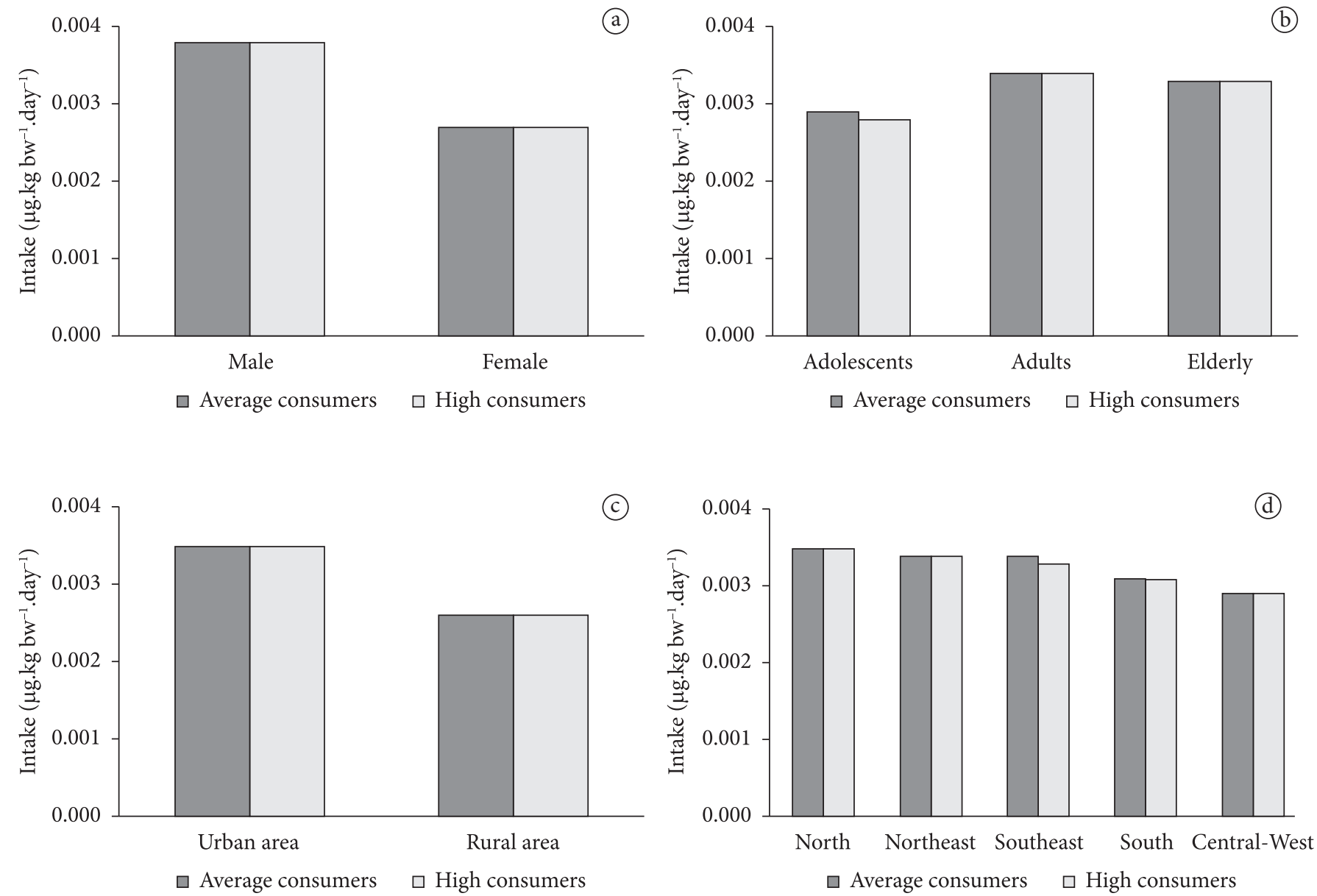

Figure 4. Estimated intakes of 1,3-DCP $\left(\mu \mathrm{g} \cdot \mathrm{kg} \mathrm{bw}^{-1} \cdot \mathrm{day}^{-1}\right)$ according to gender (a), age (b), area of residence (c), and geographic region (d). 
the consumption of an individual food is due only to the consumption of some selected items that compose this food. This could overestimate the chloropropanols intakes since other items, which are probably not contaminated, also contribute to the mean consumption reported for the food. On the other hand, it should be noted that the consumption of some highly contaminated foods was not included in the POF 2008-2009, which could underestimate the results. This is the case of frozen meals, for which 3-MCPD levels up to $2529 \mu \mathrm{g} \cdot \mathrm{kg}^{-1}$ were found in a specific brand (data not shown). Finally, individuals who consume large amounts of foods containing the chemical were not considered in this assessment, which could underestimate the exposure levels of high consumers.

As for the analytical data, some considerations must also be pointed. Although about 150 samples were taken in this study, the chloropropanol levels in some foods were calculated based on the results of a few samples (ex: frankfurter, bologna). Therefore, increasing the number of samples for these foods could provide a more precise estimate of the mean/P95 concentrations of 3-MCPD and 1,3-DCP. Moreover, the samples were only collected in the Campinas area and, although the sampling included brands that are probably commercialized in other Brazilian regions, they may not be representative of the national food supply. In spite of this, it was assumed that the levels of 3-MCPD and 1,3-DCP reported in this study represent the occurrence level of all similar foods consumed in the whole country. Assumptions regarding analytical results below LOD or LOQ may also contribute to the total uncertainty, especially when a very high number of not detected samples is considered, as in the case of 1,3-DCP.

Even considering the assumptions and limitations of this study, it is likely that the 3-MCPD intake for average and high consumers is still below the PMTDI of $2 \mu \mathrm{g} \cdot \mathrm{kg}^{-1} \mathrm{bw}$, and that the MOE for 1,3-DCP is much higher than 10000, which would suggest that the risks to human health in relation to the presence of chloropropanols in foods are low. However, a potential concern may arise for individuals who consume specific brands of frozen meals containing very high concentrations of 3-MCPD. For illustration purposes, the consumption of $250 \mathrm{~g}$ in a day of a meal containing $2529 \mu \mathrm{g} . \mathrm{kg}^{-1}$ could result in a 3-MCPD intake of $10.5 \mu \mathrm{g} . \mathrm{kg} \mathrm{bw}^{-1}$.day ${ }^{-1}$, considering a body weight of $60 \mathrm{~kg}$. This value is approximately 5 -fold higher than the PMTDI and may pose some concern for these target consumers.

It should be mentioned that the samples of frozen meals which presented very high concentrations of 3-MCPD contained added HVP, as informed on the label of the products. Therefore, it is highly likely that this ingredient was the source of contamination of these products. According to these observations, it is important to monitor and control the 3-MCPD content in the HVP that is added to food as a savory ingredient, as well as to stimulate the reduction of 3-MCPD levels during the production of acid-HVP.

For that, international strategies in risk management of chloropropanols levels in HVP that include a Code of Practices developed by the Codex Alimentarius Commission (CODEX..., 2008) and the establishment of maximum permitted levels in some countries (HAMLET; SADD, 2009) should be considered. With regard to the Code of Practices, three main approaches may be adopted for the reduction of 3-MCPD levels in HVP produced by acid hydrolysis: the first of these involves careful control of the acid hydrolysis step; the second, subsequent neutralization to minimize 3-MCPD formation; and the third makes use of sulfuric acid as a substitute for hydrochloric acid in the hydrolysis step (CODEX..., 2008). Regarding regulatory actions, maximum permitted levels from 0.02 to $1 \mathrm{mg} \cdot \mathrm{kg}^{-1}$ have been established in China, European Union, Korea, Malaysia, and United States (HAMLET; SADD, 2009), but no official limits have been set in Brazil so far.

\section{Conclusions}

This study reported the results of a preliminary estimate of the dietary intake of chloropropanols and health risk assessment in Brazil. The total exposure to 3-MCPD was about the same order of magnitude when compared to the exposures estimated in other countries, whereas that for 1,3-DCP was lower than those previously reported. Based on the intakes estimated in this study, it could be suggested that the overall risk to human health in relation to the presence of chloropropanols in foods is low. However, a potential concern may arise for individuals who consume specific brands of particular foods, such as frozen meals, which showed very high concentrations of 3-MCPD, probably due to the addition of acid-HVP as a savory ingredient. Thus, it is important to consider the introduction of potential risk management actions during the production of acid-HVP in order to protect consumer health from the increased risks associated to the occurrence of 3-MCPD in this ingredient.

\section{Acknowledgements}

Financial support was provided by the National Council for Scientific and Technological Development, Ministry of Agriculture, Livestock and Food Supply, and Secretariat of Animal and Plant Health and Inspection (CPNq/MAPA/SDA Proc. 578381/2008-7).

\section{References}

BAER, I.; DE LA CALLE, B.; TAYLOR, P. 3-MCPD in food other than soy sauce or hydrolysed vegetable protein (HVP). Analytical and Bioanalytical Chemistry, v. 396, n. 1, p. 443-456, 2010. PMid:19841911. http://dx.doi.org/10.1007/s00216-009-3177-y

BRERETON, P. et al. Determination of 3-monochloropropane-1,2-diol in food and food ingredients using mass spectrometric detection: collaborative study. Journal of AOAC International, v. 84, n. 2, p. 455-465, 2001. PMid:11324611.

CODEX ALIMENTARIUS COMMISSION - CAC. Code of Practices for the reduction of 3-monochloropropane-1,2-diol (3-MCPD) during the production of acid-hydrolised vegetable proteins (acid-HVPs) and products that contain acid-HVPs. CAC, 2008. (CAC/RCP n. 64).

DORNE, J. L. C. M. et al. Combining analytical techniques, exposure assessment and biological effects for risk assessment of chemicals in food. Trends in Analytical Chemistry, v. 28, n. 6, p. 695-707, 2009. http://dx.doi.org/10.1016/j.trac.2009.03.008

EUROPEAN FOOD SAFETY AUTHORITY - EFSA. Opinion on a harmonized approach for risk assessment of compounds which 
are both genotoxic and carcinogenic. The EFSA Journal, v. 282, p. 1-31, 2005.

FOOD AND AGRICULTURE ORGANIZATION - FAO; WORLD HEALTH ORGANIZATION - WHO. Toxicological Evaluation of Certain Food Additives and Contaminants. Genebra: FAO/ WHO, 1993. (WHO Food Additives Series n. 32). Disponível em: $<$ http://www.inchem.org/documents/jecfa/jecmono/v32je01.htm>. Acesso em: 17 jul. 2012.

FOOD AND AGRICULTURE ORGANIZATION - FAO; WORLD HEALTH ORGANIZATION - WHO. Safety Evaluation of Certain Food Additives and Contaminants. Genebra: FAO/WHO, 2002. (WHO Food Additives Series n. 48). Disponível em: <http://www. inchem.org/documents/jecfa/jecmono/v48je01.htm>. Acesso em: 17 jul. 2012.

FOOD AND AGRICULTURE ORGANIZATION - FAO; WORLD HEALTH ORGANIZATION - WHO. Safety Evaluation of Certain Food Additives and Contaminants. Genebra: FAO/WHO, 2007. p. 209-267. (WHO Food Additives Series n. 58).

FOOD ANDENVIRONMENTAL HYGIENEDEPARTMENT - FEHD. Dietary exposure to chloropropanols of secondary school students. In: FOOD AND ENVIRONMENTAL HYGIENE DEPARTMENT - FEHD. Centre for Food Safety. Risk Assessment Studies. Hong Kong: FEHD, 2007. Report n. 29. Disponível em: $<$ http://www.cfs.gov.hk/english/programme/programme_rafs/ files/RAS29_Chloropropanols_Final.pdf>. Acesso em: 17 jul. 2012.

HAMLET, C. G.; JAYARATNE, S. M.; MATTHEWS, W. 3-monochloropropane-1,2-diol (3-MCPD) in food ingredients from UK food producers and ingredient suppliers. Food Additives and Contaminants, v. 19, n. 1, p. 15-21, 2002. PMid:11817372. http://dx.doi.org/10.1080/02652030110072344

HAMLET, C. G.; SADD, P. A. Chloropropanols and chloroesters. In: STADLER, R. H.; LINEBACK, D. R. (Eds.). Process-Induced Food Toxicants: Occurrence, Formation, Mitigation, and Health Risks. Hoboken: John Wiley \& Sons Inc., 2009. cap. 2.6, p. 175-214.

INSTITUTO BRASILEIRO DE GEOGRAFIA E ESTATÍSTICA - IBGE. Pesquisa de Orçamentos Familiares 2002-2003. Aquisição alimentar domiciliar per capita - Brasil e Grandes Regiões. Rio de Janeiro: IBGE, 2004. Disponível em: <http://www.ibge.gov.br/ home/estatistica/populacao/condicaodevida/pof/2002aquisicao/ default.shtm>. Acesso em: 17 jul. 2012.

INSTITUTO BRASILEIRO DE GEOGRAFIA E ESTATÍSTICA - IBGE. Pesquisa de Orçamentos Familiares 2008-2009. Rio de Janeiro: IBGE, 2010a. Disponível em: <http://www.ibge.gov.br/home/xml/ pof_2008_2009.shtm>. Acesso em: 17 jul. 2012.

INSTITUTO BRASILEIRO DE GEOGRAFIA E ESTATÍSTICA - IBGE. Antropometria e estado nutricional de crianças, adolescentes e adultos no Brasil. In: INSTITUTO BRASILEIRO DE GEOGRAFIA E ESTATÍSTICA - IBGE. Pesquisa de Orçamentos Familiares 2008-2009. Rio de Janeiro: IBGE, 2010b. Disponível em: <http:// www.ibge.gov.br/home/estatistica/populacao/condicaodevida/ pof/2008_2009_encaa/default.shtm>. Acesso em: 17 jul. 2012.
INSTITUTO BRASILEIRO DE GEOGRAFIA E ESTATÍSTICA - IBGE. Pesquisa de Orçamentos Familiares 2008-2009. Análise do Consumo Alimentar Pessoal no Brasil. Rio de Janeiro: IBGE, 2011. Disponível em: <http://www.ibge.gov.br/home/estatistica/ populacao/condicaodevida/pof/2008_2009_analise_consumo/ default.shtm>. Acesso em: 17 jul. 2012.

INTERNATIONAL AGENCY FOR RESEARCH ON CANCER - IARC. 3-Monochloropropane-1,2-diol. Lyon: IARC, 2012a. (Monographs, n. 101). Disponível em: <http:// monographs.iarc.fr/ENG/Monographs/vol101/mono101-010.pdf >. Acesso em: 17 jul. 2012.

INTERNATIONAL AGENCY FOR RESEARCH ON CANCER - IARC. 1,3-Dichloro-2-propanol. Lyon: IARC, 2012a. (Monographs, n. 101). Disponível em: <http://monographs.iarc. fr/ENG/Monographs/vol101/mono101-011.pdf >. Acesso em: 17 jul. 2012.

JARDIM, A. N. O.; CALDAS, E. D. Exposição humana a substâncias químicas potencialmente tóxicas na dieta e os riscos para saúde. Química Nova, v. 32, n. 7, p. 1898-1909, 2009. http://dx.doi. org/10.1590/S0100-40422009000700036

KROES, R. et al. Assessment of intake from the diet. Food and Chemical Toxicology, v. 40, n. 2-3, p. 327-385, 2002. http://dx.doi. org/10.1016/S0278-6915(01)00113-2

LÉON, N. et al. Determination of 3-MCPD by GC-MS/MS with PTVLV injector used for a survey of Spanish foodstuffs. Talanta, v. 75, n. 3, p. 824-831, 2008. PMid:18585153. http://dx.doi.org/10.1016/j. talanta.2007.12.028

LIM, I. G. et al. A sensitive method for determination of 1,3dichloropropane-2-ol and 3-monochloropropane-1,2-diol in sauces using gas capillary chromatography with mass spectrometry. Singapore Journal of Primary Industries, v. 32, p. 30-45, 2005.

UNITED KINGDOM. Ministry of Agriculture, Fisheries and Food - MAFF. Survey of 3-monochloropropane-1,2-diol (3-mcpd) in soy sauce and similar products. London: MAFF, 1999. (Food surveillance information sheet $\mathrm{n} .187)$. Disponível: $<$ http://archive. food.gov.uk/maff/archive/food/infsheet/1999/no187/187soy.htm>. Acesso em: 17 jul. 2012.

VELÍŠEK, J. et al. Chlorohydrins in protein hydrolysates. Zeitschrift für Lebensmitteluntersuchung und -Forschung A, v. 167, n. 4, p. 241-244, 1978.

VELÍŠEK, J. Chloropropanols. In: STADLER, R. H.; LINEBACK, D. R. (Eds.). Process-Induced Food Toxicants: Occurrence, Formation, Mitigation, and Health Risks. Hoboken: John Wiley \& Sons Inc., 2009. cap. 6.3, p. 539-562.

WORLD HEALTH ORGANIZATION - WHO. Instructions for electronic submission of data on chemical contaminants in foods - Appendix 5: Evaluation of low level contamination in foods. In: WORLD HEALTH ORGANIZATION - WHO. Food Contamination Monitoring and Assessment Program (GEMS/ FOOD). Genebra: WHO, 2002. Disponível em: <ftp://ftp.ksph. kz/Chemistry_Food\%20Safety/TotalDietStudies/Chemical.pdf $>$. Acesso em: 17 jul. 2012. 